\title{
COMUNICAÇÃo
}

\section{INFECÇÃO EXPERIMENTAL DO HAMSTER PELO TRYPANOSOMA CRUZI: FASE CRÔNICA}

\author{
L.E. Ramirez, E. Lages-Silva, J.M. Soares Junior e E. Chapadeiro
}

Em comunicação anterior ${ }^{4}$ confirmamos que 0 hamster é susceptível à infecção pelo $T$. cruzi ${ }^{1235}$, visto que ele reproduz as lesões da fase aguda, tais como: cardite, miosite e ganglionite do tubo gastrointestinal, pancreatite, hepatite e sialoadenite, meningoencefalite, celulite, epididimite, vesiculite, prostatite e funiculite, semelhantes às encontradas no homem e em outros modelos experimentais.

Com o objetivo de estudar a infecção por um periodo prolongado, a partir do terceiro mês, inoculamos 46 hamsters, 22 machos e 24 fêmeas, via intraperitoneal com 35.000 tripomastigotas sangüíneos do $T$. cruzi, provenientes de camundongos infectados com as cepas $Y$, Benedito e Vicentina, essas últimas isoladas em nosso laboratório de pacientes chagásicos crônicos, oriundos do Triângulo Mineiro e portadores de formas indeterminada e cardio-digestiva, respectivamente. Trinta dias após a inoculação a parasitemia, detectada através do exame a fresco, foi negativa, porém positiva pelo método de concentração do microhematócrito e/ou hemocultura em várias ocasiões.

A necrópsia dos animais mortos subitamente e/ ou sacrificados mostrou: corações dilatados e congestos com derrame de líquido pericárdico; congestão pulmonar e derrame pleural; congestão e degeneração gordurosa do fígado; congestão do baço; palidez intestinal e sinais de atrofia. Nas fêmeas havia atrofia e palidez do útero e ovários; nos machos, atrofia dos testículos. Em dez casos foi encontrada ascite de grau variável.

A partir do terceiro mês alguns animais se apresentavam em mau estado geral (apáticos, dispnéicos, com queda acentuada de pêlos e edemaciados) e foram sacrificados. Outros, em bom estado geral, morreram subitamente es demais

\footnotetext{
Trabalho da Disciplina de Parasitologia e Pós-graduação em Patologia Humana. Faculdade de Medicina do Triângulo Mineiro, Uberaba, MG.

Órgāo de Apoio: FMTM-FUNEPU, CNPq E FAPEMIG Endereço para correspondência: Dr. Luis Eduardo Ramirez. Disc. de Parasitologia/FMTM. Pça. Thomaz Ulhoa 706, 38025-050 Uberaba, MG.

Recebido para publicaçāo em $06 / 10 / 93$.
}

foram sacrificados em períodos pré-estabelecidos a cada trinta dias até o décimo mês.

O exame histológico do coração mostrou pancardite crônica: epicardite comprometendo os gânglios atriais (ganglionite) e filetes nervosos (neurite); endocardite discreta e de aspecto focal. miocardite multifocal e/ou zonal com destruição de miocélulas do tecido funcional e do tecido excitocondutor. Ao lado do infiltrado inflamatório havia neoformação conjuntiva (fibrose) de grau variável em substituição às fibras destruídas (Figuras 1 e 2).

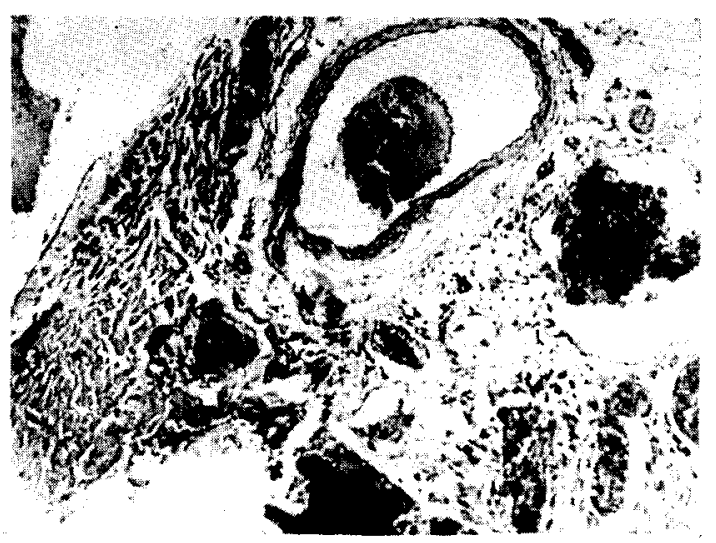

Figura 1 - Coração: epicardite e miocardite crônicas focais. $H E 40 x$.

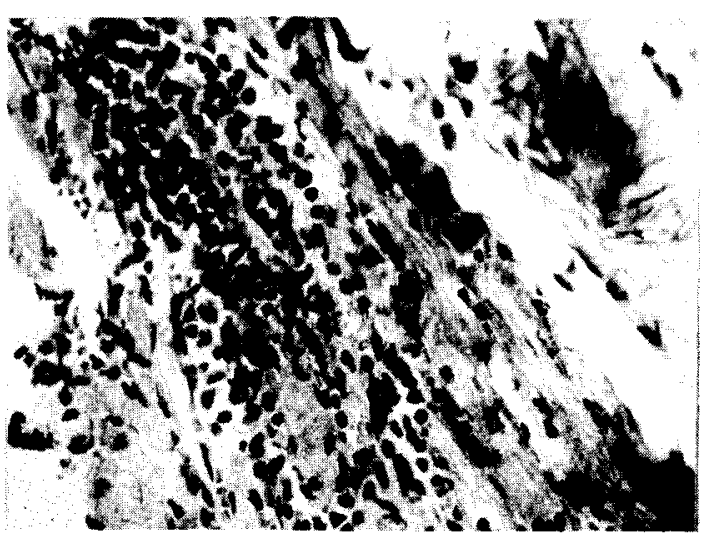

Figura 2 - Coração: miocardite crônica fibrosante. Detalhe do infiltrado mononuclear entre fibrocélulas rotas. $H E 400 x$. 
Comunicação. Infeç̧âo experimental do hamster pelo Trypanosoma cruzi: fase crônica. Revista da Sociedade Brasileira de Medicina Tropical 26:253-254, out-dez, 1993.

A musculatura estriada apresentava miosite multifocal endo e perimisial com necrose focal das miocélulas e discreta fibrose de substituição (Figura 3).

No tubo digestivo, observou-se miosite e ganglionite com graus variáveis de destruição neuronal (Figura 4). As glândulas anexas do tubo digestivo apresentaram focos de infiltrados de células mononucleares com tendência, no fígado, à formação de nódulos de células epitelióides intralobulares e infiltração gordurosa e atrofia do parênquima pancreático.

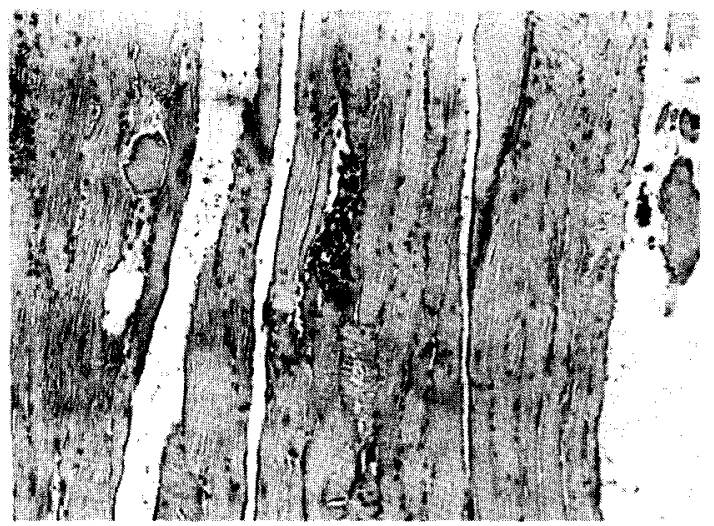

Figura 3 - Müsculo esquelético: miosite crônica focal (seta); infiltrado de células mononucleares envolvendo restos necróticos. $H E 100 x$.

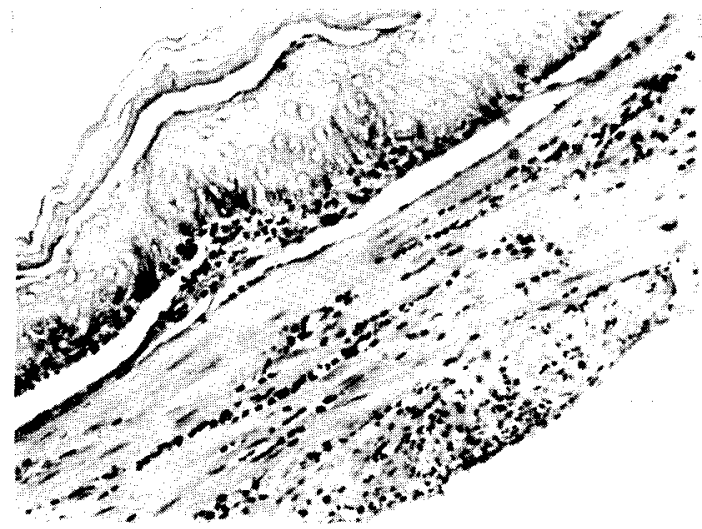

Figura 4 - Esôfago: infiltrado mononuclear acentuado na musculatur própria (miosite) e em correspondência com os gânglios (ganglionite) do plexo mioentérico.

O exame microscópio dos pulmões confirmou os achados macroscópicos de congestão crônica passiva.

$\mathrm{O}$ útero e ovário apresentaram inflamação crônica com sinais de fibrose e atrofia (ooforite e metrite crônicas fibrosantes). Nos machos observou- se: orquite crônica necrosante com atrofia dos testículos, epididimite, funiculite, vesciculite e prostatite crônicas com infiltrado de células mononucleares. No sistema urinário cistite $e$ ureterite focais discretas.

O timo mostrava sinais de depleção linfócitica com atrofia; o baço era congesto e em alguns animais foram encontrados depóstitos de material amilóide (Vermelho Congo positivo); os linfonodos apresentaram também depleção linfocítica com intensa plasmocitose.

No SNC, a inflamação (meningoencefalite) era focal e discreta sob a forma de pequenos infiltrados de células mononucleares e células gliais. Além dos gânglios autônomos parassimpáticos do coração e do tubo digestivo, os gânglios do plexo hipogástrico e da cadeia simpática mostraram focos de infiltrado mononuclear de intensidade variável.

A medula óssea e a adrenal não apresentaram alterações.

Em nenhum dos órgãos citados foram observados formas amastigotas; entretanto como já foi assinalado foram encontrados parasitas circulantes através do método de concentração do microhematócrito e/ou hemocultura. Em alguns animais foram encontrados tripomastigotas no líquido pericárdico e/ou pleural, através dos métodos parasitológicos citados.

Anticorpos líticos foram detectados através da reação de lise mediada por complemento (LMC).

Em conclusão, pode-se afirmar que o hamster reproduz também a fase crônica da infecção pelo T. cruzi, do ponto de vista parasitológico, sorológico, histopatológico e clínico.

\section{REFERÊNCIAS BIBLIOGRÁFICAS}

1. Bijovsky AT, Milder RV, Abrahamsohn IA, Sinhorini IL, Mariano L. The influence of lymphatic drainage in experimental Trypanos sma cruzi infection. Acta Tropica 41:207-214, 1984

2. Cariola J, Prado R, Agosin M, Christen R Susceptibilidad del hamster (Cricetus auratus) \& Peromyscus (Peromyscus maniculatus gambeli), a la infección experimental por Trypanosoma cruzi, cepa tulahuén. Boletin Informativo Parasitarias Chilenas V:44-45, 1950.

3. Osimani JJ, Criva J. Infección experimental del hamster dorado (Mesocricetus auratus) con algunas cepas Uruguayas de Trypanosoma cruzi. Archivos de la Sociedad de Biologia de Montevideo XVIII:7378, 1954.

4. Ramirez LE, Lages-Silva E, Chapadeiro E. Infecção do hamster pelo Trypanosoma cruzi. Revista da Sociedade Brasileira de Medicina Tropical 24:119$120,1991$.

5. Shoemaker JP, Hoffman JrRV. Trypanosoma cruzi: Possible stimulatory factor(s) in brown adipose tissue in mice. Experimental Parasitology 35:272274,1971 . 